\title{
The Processing of Pinus radiata: Pore Size Distribution Changes in the Cell Wall Structure Studied by Pressure Plate Technique and Mercury Intrusion Porosimetry
}

\begin{abstract}
Dante Giacomozzi, ${ }^{a}$ Olli Joutsimo, ${ }^{a}$ and Samuel L. Zelinka ${ }^{b}$
The pore size distribution of cell walls in softwood pulps was studied using the pressure plate technique and mercury intrusion porosimetry, which together make it possible to cover the range from $10^{1}$ to $10^{6} \mathrm{~nm}$ in pore sizes (mesopores and macropores). The differences in pore size distribution between never-dried pulp from a fiber line, industrially-dried pulp, and laboratory-dried pulps were evaluated. The results showed an increase in the relative pore volume (100 to 2,000 nm) between industrial washing and bleaching stages. Also, mercury porosimetry showed a broadening of the pore size distribution of cell walls after industrial drying. Results showed that, besides the changes in micropore and mesopore size distributions, the macropore range is also affected by processing and drying.
\end{abstract}

Keywords: Cell wall; Pore size distribution; Mercury intrusion; Pressure plate

Contact information: a: Bioforest S. A., Coronel, Región del Bio-Bio, Chile; b: Forest Products Laboratory, Forest Service, United States Department of Agriculture, USA;

*Corresponding author: dgiacomozzi@arauco.cl

\section{INTRODUCTION}

During kraft processing, the main components of wood (lignin, cellulose, hemicelluloses, and extractives) are subjected to dissolution and removal to different extents. These chemical changes are accompanied by physical changes such as the development of an inner porous structure in the cell wall (Stone and Scallan 1965, 1968; Allan et al. 1991; Andreasson et al. 2003). This porous structure evolves during processing and modifies properties, e.g., the surface and bulk charges, fiber shape, conformability, strength, swelling behavior, water holding ability, and others (de Ruvo and Htun 1983; Andreasson et al. 2003). Additional changes in the pore structure and properties of the pulps are observed during drying and rewetting cycles, which are integrated in the hornification concept (Jayme 1944). Available techniques to measure changes in porosity of the cell wall are: nitrogen adsorption (Stone and Scallan 1965), mercury porosimetry (MIP) (Moura et al. 2005; Giesche 2006; Yamauchi 2007), solute exclusion (Stone and Scallan 1968; Lin et al. 1987; Allan 1991), proton nuclear magnetic resonance (H-NMR) (Li 1993), differential scanning calorimetry (Maloney and Paulapuro 1998; Park et al. 2006), atomic force microscopy AFM (Fahlén and Salmén 2005), scanning electron microscopy SEM (Lovikka et al. 2016), and transmission electron microscopy (TEM), among others.

Hill and Papadopoulos (2001) reviewed various methods to measure the porosity of the cell wall. Each technique has a fixed range of pore sizes that can be measured, and each method has specimen preparation limitations. For example, size exclusion 
chromatography measures pores in the range of approximately $0.8 \mathrm{~nm}$ to $13 \mathrm{~nm}$ (Lin et al. 1987; Berthold and Salmén 1997), while H-NMR measures pores in the range of $0 \mathrm{~nm}$ to $30 \mathrm{~nm}$ ( $\mathrm{Li}$ and Henriksson 1993; Andreasson et al. 2005). The ranges for nitrogen adsorption technique varies between authors from 1 to $50 \mathrm{~nm}$ (Anovitz and Cole 2015), 1 to $300 \mathrm{~nm}$ (Westermarck 2000), and even <400 nm (Kimura et al. 2014, 2016). In comparison, X-ray methods are limited to determining the volume of pores that are no more than $300 \AA(30 \mathrm{~nm})$ in radius. A summary of available methods and the ranges in pore diameter are presented in Fig. 1.

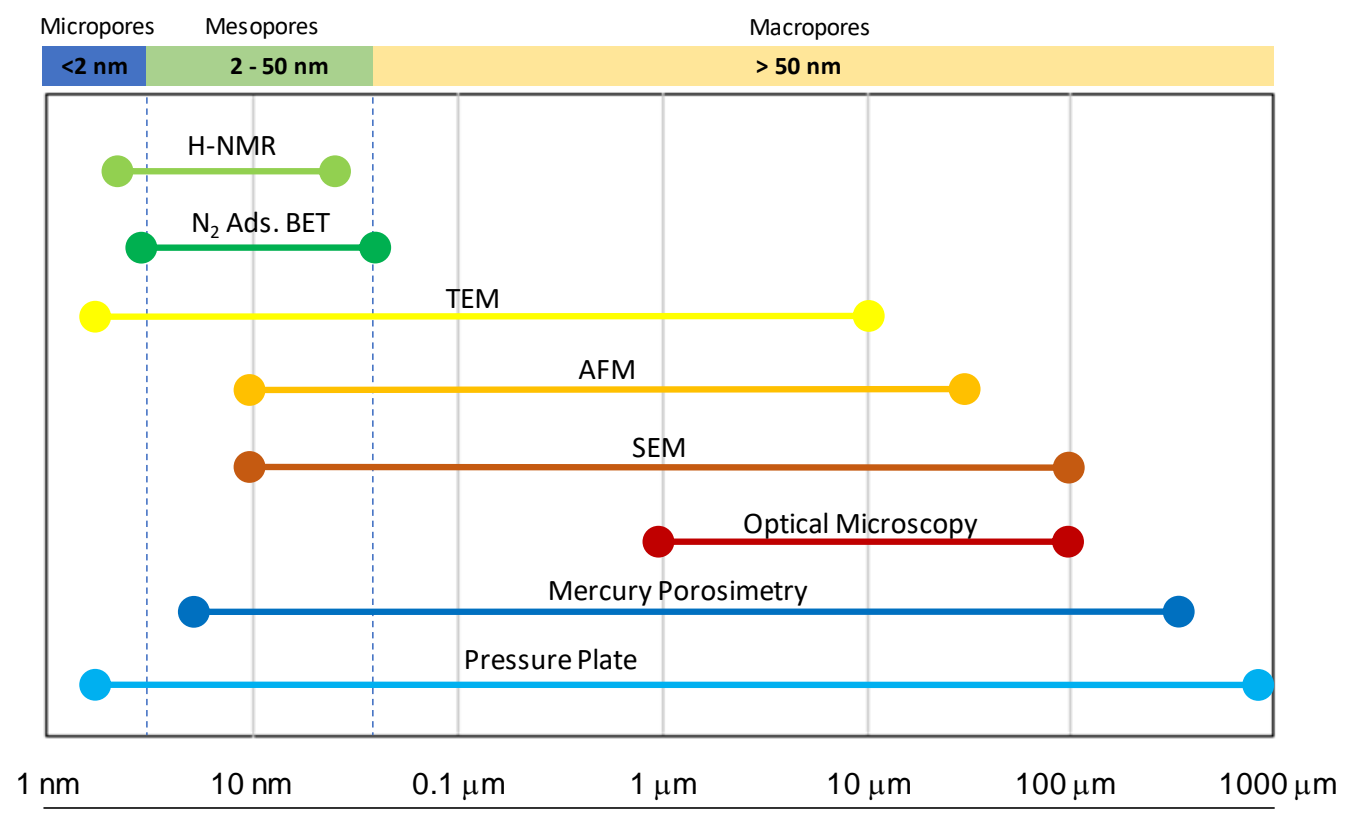

Fig. 1. Techniques to measure porosity and pore size distribution and typical ranges

One of the main questions regarding porosity changes of the pulp fibers is related to how the macropores behave during processing and drying (presence, absence, creation or loss of larger pores). According to Anovitz and Cole (2015), useful techniques to measure porosity in a wide range (including macropores up to $100 \mu \mathrm{m}$ ), are mercury intrusion porosimetry (MIP), mercury picnometry and water immersion porosimetry, optical microscopy, SEM, and AFM (to a slightly lower pore sizes compared to SEM).

In MIP, the relative pore volume is determined by the mercury volume imbibed by a dry pulp sample at a given pressure. The main advantages of MIP are related to the possibility of measuring a wide range of pore sizes, between $3.5 \mathrm{~nm}$ and $500 \mu \mathrm{m}$ (Giesche 2006). Also, it provides information about the pore size distribution, total pore volume, and specific surface area of a sample. The main drawback of this technique is related to the assumption of cylindrical geometry of the pores, which requires a careful analysis of the results (Moura 2005). Along the same lines, sample compressibility, assumption of interconnected pores and inability of identifying narrow necked voids must also be considered and overcome by correction procedures (Chinga 2002).

The pressure plate technique is used to measure the pore size distribution over a similar range of pore sizes as MIP but it requires water-saturated samples. Samples are 
subjected to increasing pressures until an equilibrium condition is reached (Stone and Scallan 1967).

Scanning electron microscopy (SEM) offers high resolution, magnification power, and image quality. When SEM is used in combination with image analysis techniques, it can be used to study fibres dimensions, porosity, paper morphology, and coating layer structure details (Chinga 2002). SEM is useful in covering a size range from mesopores to macropores (Anovitz and Cole 2015; Lovikka et al. 2016),

While these techniques measure over a similar range of pore sizes, the MIP technique utilizes dry samples whereas the pressure plate technique measures from the saturated state. Furthermore, by extending the moisture retention curve using the water vapor sorption isotherm in the hygroscopic region, it is possible to extend the projections of the pore size distribution to nanopores (Roels et al. 2001; Carmeliet and Roels 2002; Zillig 2009). Therefore, the pore size distribution of industrial and laboratory pulps was studied using a combination of the pressure plate technique, MIP, and desorption isotherms.

\section{EXPERIMENTAL}

\section{Materials}

The pore size distribution studies were conducted with 10 Pinus radiata pulp samples from industrial and laboratory sources (Table 1).

Table 1. Mill and Laboratory Never Dried and Dried Pulp Samples

\begin{tabular}{|c|c|c|c|}
\hline Sample & Sample Description & Source & Condition \\
\hline S0 & Brown pulp from industrial chips & Laboratory & Never dried \\
\hline S1 & Bleached pulp from industrial chips & Laboratory & Never dried \\
\hline S2 & Digester pulp - Blow line & Mill & Never dried \\
\hline S3 & Pulp from atmospheric diffuser (discharge) & Mill & Never dried \\
\hline S4 & Discharge from washing area (pre $\mathrm{O}_{2}$ press) & Mill & Never dried \\
\hline S5 & Discharge from post O $_{2}$ press & Mill & Never dried \\
\hline S6 & Bleached pulp - Machine chest & Mill & Never dried \\
\hline S7 & Industrially-dried (pulp sheets) & Mill & Dried \\
\hline S8 & Lab-dried (from S6) - Air-dried to $92 \%$ dryness & Mill/Laboratory & Dried \\
\hline S9 & Lab-dried (from S6) - Oven-dried at $105^{\circ} \mathrm{C}$ to & \multirow{2}{*}{ Mill/Laboratory } & Dried \\
\hline
\end{tabular}

\section{Methods}

Sampling of the industrial pulp and sample management

The industrial pulp samples (S2 through S7) were obtained during the normal operation of a softwood mill (Arauco Mill Line 2, Horcones, Arauco, Chile). Each sample ( $5 \mathrm{~kg}$ oven-dried) was taken from three batches, and they were sampled within a period of $2 \mathrm{~h}$.

The residence times along the fiber line were also considered between samples. After completion of the three batches, the pulp from each sampling point were thoroughly mixed and homogenized. The pulp suspensions (S2 through S6) were gently dewatered by 
hand to avoid mechanical damage and stored at $2{ }^{\circ} \mathrm{C}$ before testing. The industrially-dried pulp sheets (S7) were hand chopped, homogenized, and stored after discarding the edges.

\section{Production of the laboratory pulp}

The laboratory pulp was produced with industrial $P$. radiata chips $(200 \mathrm{~kg})$ that were obtained from the wood yard of the mill where the industrial pulp was sampled. The chips were homogenized (TAPPI $257 \mathrm{~cm}-02$ (2002)) and screened (SCAN CM 40:01 (2001)) to a separate the accepted fraction that was used for the study. Other screening fractions were discarded. After homogenization, the dry content of the accepted chips was measured (SCAN CM 39:94 (1994)), and the sample was later separated into sealed bags ( $850 \mathrm{~g}$ of dry chips in each) for storage at $4{ }^{\circ} \mathrm{C}$ in a cold chamber until cooking.

The chips were cooked in the laboratory using batch digesters (10-L, MK Systems Inc., Peabody, Massachusetts, USA) equipped with liquor circulation and electrical heating. White and weak black liquors for cooking were obtained from the mill, specifically from the causticizing and evaporators area, and characterized via SCAN-N 30:85 (1985) and SCAN-N 33:94 (1994), respectively. The white liquor alkalinity was $121.4 \mathrm{~g} / \mathrm{L}$ effective alkali (as $\mathrm{NaOH}$ ) and the sulfidity was $27.9 \%$. The liquor to wood ratio was $4: 1$ and the alkali charge was $21.45 \% \mathrm{EA}(\mathrm{NaOH})$. The cooking temperature was $170{ }^{\circ} \mathrm{C}$ and the Kappa target was $30 \pm 1$. After cooking, the pulp was screened (Somerville screen, Testing Machines Inc, Delaware, USA; according to the TAPPI T275 sp12 (2012) standard) and gently dewatered by hand. A total of three cooking processes were performed and the screened pulp was mixed and homogenized to produce a base sample (approximately $1.2 \mathrm{~kg}$ oven-dried). Half of the brown pulp sample was stored for the pore size distribution analyses (Sample S0) and the other half was oxygen delignified (one stage, $20 \mathrm{~kg} / \mathrm{ADt} \mathrm{NaOH}, 10 \%$ consistency, target Kappa $=14 \pm 1$ ) and bleached (DEDD sequence, target brightness $=89 \%$ ISO) to produce the bleached pulp sample (S1).

\section{Laboratory drying of the industrial pulp}

Fractions of sample S6 were dried in the laboratory to produce samples S8 and S9. Sample S8 was obtained after air-drying at $25^{\circ} \mathrm{C}$ (free drying, 92\% to $93 \%$ final dryness), and S9 was obtained after oven-drying at $105{ }^{\circ} \mathrm{C}$ (free drying, 92\% to 93\% final dryness). All of the laboratory samples (S0, S1, S8, and S9) were stored in a cold chamber $\left(2{ }^{\circ} \mathrm{C}\right)$ until further analysis.

\section{Mercury intrusion porosimetry}

The pulps were freeze-dried and stored before the MIP studies. MIP requires dry samples, and this method was used to preserve as much structure as possible. However, even freeze-drying may affect the smallest pores (Jin et al. 2004). Freeze-drying was performed by squeezing the pulp by hand followed by freezing with liquid nitrogen. The samples were after transferred to a freeze dryer and exposed to a vacuum of $5 \mu \mathrm{m}$ to $7 \mu \mathrm{m}$ $\mathrm{Hg}(0.6 \mathrm{~Pa}$ to $0.9 \mathrm{~Pa})$ for three days. After releasing the vacuum, the samples were stored in a desiccator over $\mathrm{P}_{2} \mathrm{O}_{5}$ until further testing. The mercury filling was measured at 820 different pressures at $28{ }^{\circ} \mathrm{C}$, over a range of $1.4 \mathrm{kPa}$ to $140 \mathrm{MPa}$. These pressures corresponded to a pore radius range between $450 \mu \mathrm{m}$ to $4.5 \mathrm{~nm}$; however, the measurement of the smallest pores may be affected by the predrying or the high pressures required to measure them 


\section{Pressure plate technique}

Samples were placed on ceramic plates and treated with $0.01 \%$ thimerosal solution to prevent fungal growth. The plates were placed in a chamber where increasing pressures were applied, which caused water to leave the pulp through the plate (the applied pressure was equal in magnitude, but opposite in sign to the capillary pressure). The water was collected and measured daily. Measurements were conducted at $22{ }^{\circ} \mathrm{C}$ until the samples reached equilibrium (output water was less than or equal to $0.05 \mathrm{~mL}$ over $48 \mathrm{~h}$ ). The pulp was then oven-dried so that the moisture content (MC; mass of water per mass of dry material) could be calculated based on Eq. 1,

$$
\mathrm{MC}=\frac{m_{\mathrm{at} \text { pressure }}-m_{\mathrm{dry}}}{m_{\mathrm{dry}}}
$$

where $m_{\text {at pressure }}$ is the mass under equilibrium condition $(\mathrm{g})$ and $m_{\mathrm{dry}}$ is the mass at the oven-dry condition ( $\mathrm{g}$ ) as stated in ASTM C1699. Fifteen different pressures were examined from $0.01 \mathrm{MPa}$ to $1.5 \mathrm{MPa}$, which corresponded to the pore radius range of $14000 \mathrm{~nm}(14 \mu \mathrm{m})$ to $96 \mathrm{~nm}$.

\section{Sorption isotherms}

Sorption isotherms were collected during desorption from a saturated state. Nine relative humidity (RH) values were examined (from $90 \%$ to $10 \%$ ). The pulp was separated into small quantities (approximately $10 \mathrm{mg}$ to $20 \mathrm{mg}$ ) and treated with a droplet of $0.01 \%$ thimerosal aqueous solution. After that, the pulp was completely saturated with liquid water prior to the measurements. The samples were first conditioned in a $95 \% \mathrm{RH}$ environment by suspending them over a saturated solution of potassium nitrate $\left(\mathrm{KNO}_{3}\right)$ for several weeks until they reached equilibrium. The sorption isotherms were collected with a dynamic vapor sorption analyzer (IGAsorp, Hiden Isochema, Warrington, UK confirm), which had a microbalance with a sample basket that was suspended in a gas stream where the RH could be precisely controlled at a constant temperature $\left(25^{\circ} \mathrm{C}\right)$. The mass was collected as a function of time and the data were extrapolated by kinetic models to determine the equilibrium moisture content. In these experiments, the $\mathrm{RH}$ was held at $90 \%$ for at least $18 \mathrm{~h}$. After the $90 \%$ step, the RH was held constant for $5 \mathrm{~h}$ at each $\mathrm{RH}$, and the equilibrium mass was found by fitting the data to the parallel exponential kinetics model. The specimens were then oven-dried and the moisture content calculated using Eq. 2.

$$
\mathrm{MC}=\frac{m_{\mathrm{at} \mathrm{RH}}-m_{\mathrm{dry}}}{m_{\mathrm{dry}}}
$$

The capillary pressures (RH values between $10 \%$ and $90 \%$ ) ranged between $14 \mathrm{MPa}$ and $320 \mathrm{MPa}$, which corresponded to a pore radius range of $10 \mathrm{~nm}$ to $0.5 \mathrm{~nm}$.

\section{Data Analysis}

\section{Mercury intrusion porosimetry}

The MIP tests show the relative amount of mercury intrusion as a function of the mercury pressure. For these results, the capillary pressure was calculated from the mercury pressure with Eq. 3 (Zillig 2009),

$$
P_{c}=-P_{H g} * \frac{\gamma_{\mathrm{water}}}{\gamma_{\mathrm{Hg}} \cos \theta_{\mathrm{Hg}}}
$$


where $P_{\mathrm{Hg}}$ is the mercury pressure $(\mathrm{Pa}), \gamma_{\text {water }}$ is the surface tension of water $(0.0715 \mathrm{~N} / \mathrm{m}$ at $\left.28{ }^{\circ} \mathrm{C}\right), \gamma_{\mathrm{Hg}}$ is the surface tension of mercury $(0.480 \mathrm{~N} / \mathrm{m})$, and $\theta_{\mathrm{Hg}}$ is the contact angle of mercury (commonly taken as $140^{\circ}$ ). The contact angle of water was assumed to be $180^{\circ}$ (perfectly wetting) following the convention of Zillig (2009).

The volume of mercury intruded was related to the volume of water, and thus the MC (g of water per g of dry material) was calculated with Eq. 4 (Roels et al. 2001; Zillig 2009),

$$
\mathrm{MC}=\left[\frac{\varphi-\rho_{\text {bulk }}\left(v_{\mathrm{Hg}}-v_{\mathrm{Hg}}^{0}\right)}{\rho_{\text {bulk }}}\right] * \rho_{\mathrm{H}_{2} \mathrm{O}}
$$

where $\left(v_{\mathrm{Hg}}-v_{\mathrm{Hg}}\right)$ represents the specific volume of mercury $\left(\mathrm{m}^{3} / \mathrm{kg}\right.$ of dry material $)$ intruded at that pressure minus the specific volume of mercury intruded at the lowest pressure, $\varphi$ is the total porosity determined from the bulk and skeletal densities, and $\rho_{\text {bulk }}$ is the bulk density $\left(\mathrm{kg} / \mathrm{m}^{3}\right)$. This data was then truncated at a $\log \left|p_{\mathrm{c}}\right|$ of 7.15 , which was equivalent to $90 \% \mathrm{RH}$ and the first point from the sorption curve. The sorption curve was then linked with the MIP curve. To make a continuous curve, a constant (equal to the difference between MIP and sorption isotherm measurements at $\log \left|p_{\mathrm{c}}\right|=7.15$ ) was added to the MIP data. The data was then normalized by dividing it by the maximum moisture content. The resultant moisture retention curve gave the degree of moisture saturation for the capillary pressures of $0.3 \mathrm{kPa}$ to $300 \mathrm{MPa}$. The pore size distribution was determined by numerically differentiating the moisture retention curve. To reduce noise in the derivative, the data was filtered with the method of Savitzky-Golay (1964).

\section{Pressure plate technique}

The data results were in the form of moisture content as a function of the capillary pressure (20 points). The moisture retention curve was fit with a Van Genuchten equation (Carmeliet and Roels 2002; Roels et al. 2001),

$$
M C=M C_{\max } \sum_{i=1}^{Z} l_{i}\left[1+\left(a_{i} p_{c}\right)^{n_{i}}\right]^{-m_{i}}
$$

where $Z$ is the number of pore systems present.

This function is frequently used to describe the moisture retention curve in soils and other porous materials and can be analytically differentiated to determine the pore size distribution (Carmeliet and Roels 2002; Roels et al. 2001; Zelinka et al. 2016; Zillig et al. 2006). The Van Genuchten equation treats each pore distribution independently (i.e. parallel); the pore systems are summed to get the total moisture content at a given capillary pressure. The data were fit with $Z=2$ and $Z=3$. It was found that the data were best fit with $Z=2$, implying that there were two independent pore systems in this pressure regime.

\section{RESULTS AND DISCUSSION}

In this section, the pore size distribution results are presented and discussed for mercury intrusion porosity and pressure plate technique. Note that pore size distributions presented are normalized. This allows for the partitioning of the two pore systems to be compared across different treatments. Furthermore, the total porosity was not able to be 
accurately determined in either the MIP or the pressure plate technique, as the sample volumes of the water saturated pulps are ill-defined.

\section{Mercury Intrusion Porosimetry}

The pore size distributions based on the MIP data are presented in Figs. 2 through 5.

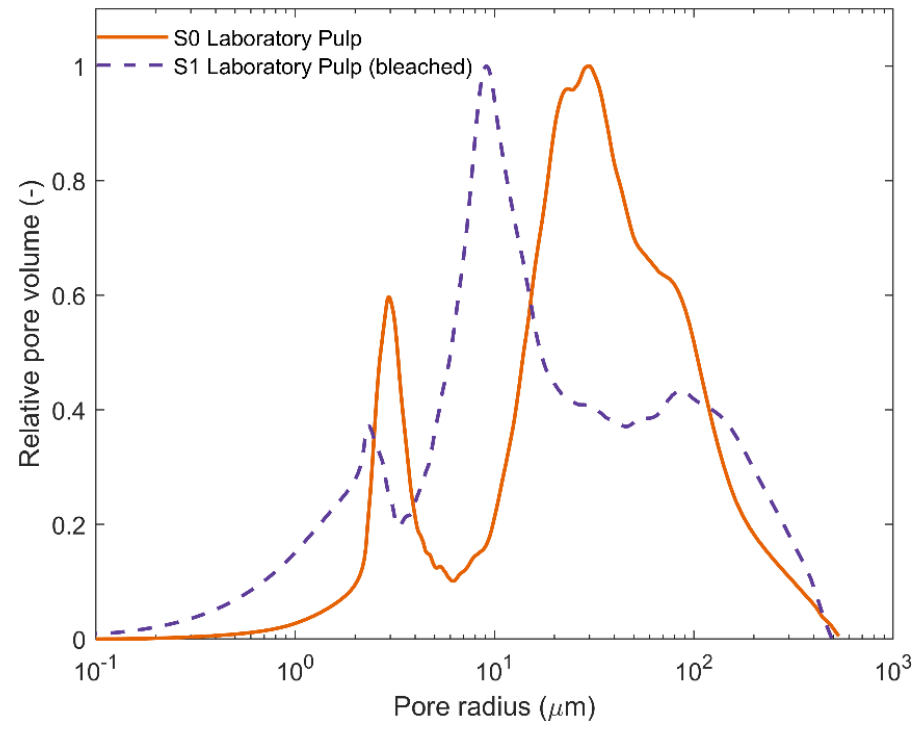

Fig. 2. Pore size distribution results for the laboratory pulp from the cooking stage (SO) and after bleaching (S1) based on the MIP data taken on freeze-dried pulps

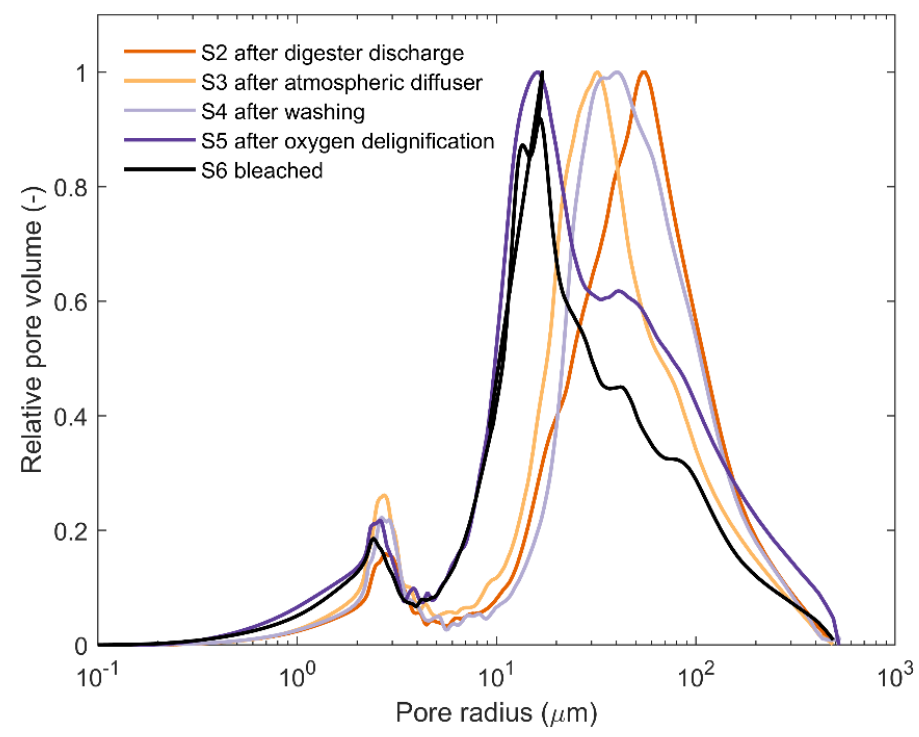

Fig. 3. Pore size distribution results for the industrial pulp sampled during the process, from digester discharge to bleaching (S2 through S6), based on the MIP data taken on freeze-dried pulps

In Fig. 2, where the laboratory pulp from bleaching (S1) and cooking (S0) are compared, in the S1 sample the radii of both pore systems was smaller than the pore systems in S0. This shift was observable in both main peaks. The peak from the largest 
pore system decreased from $30 \mu \mathrm{m}$ to $20 \mu \mathrm{m}$, and the smaller pore system peak decreased from $2 \mu \mathrm{m}$ to $1 \mu \mathrm{m}$. In Fig. 3, the industrial pulps (from S2 to S6) showed similar shifts towards lower pore radii for the peaks above and below $10 \mu \mathrm{m}$. These changes in pore size distribution are probably due to creation of new pores in the cell walls during processing (related to chemical dissolution and an increase in the accessibility of the cell wall). In the pore size range of $0.1 \mu \mathrm{m}$ to $1 \mu \mathrm{m}$ (Fig. 4), the relative peak height and tail of the distribution increased, which indicated that more pores between $100 \mathrm{~nm}$ to $1000 \mathrm{~nm}$ were created. Most of the changes in the pore size distribution occurred between the washing (S4) and oxygen delignification (S5) steps, with a remarkable increase in the relative volume for pores in the range of $100 \mathrm{~nm}$ to $2000 \mathrm{~nm}$ in size.

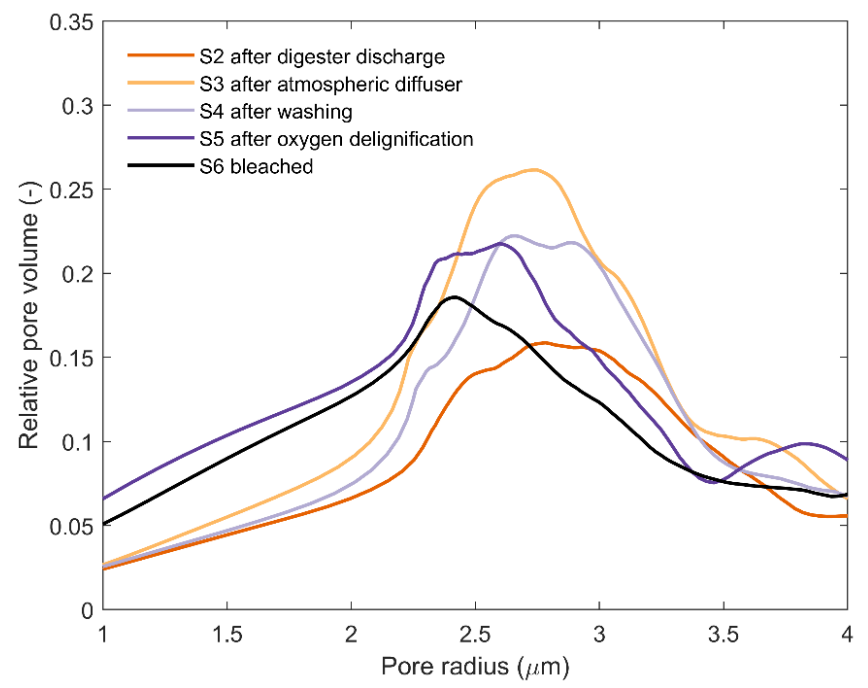

Fig. 4. Pore size distribution results in the range of $1 \mu \mathrm{m}$ to $4 \mu \mathrm{m}$ for the industrial pulp sampled during the process, from digester discharge to bleaching (S2 to S6), based on the MIP data

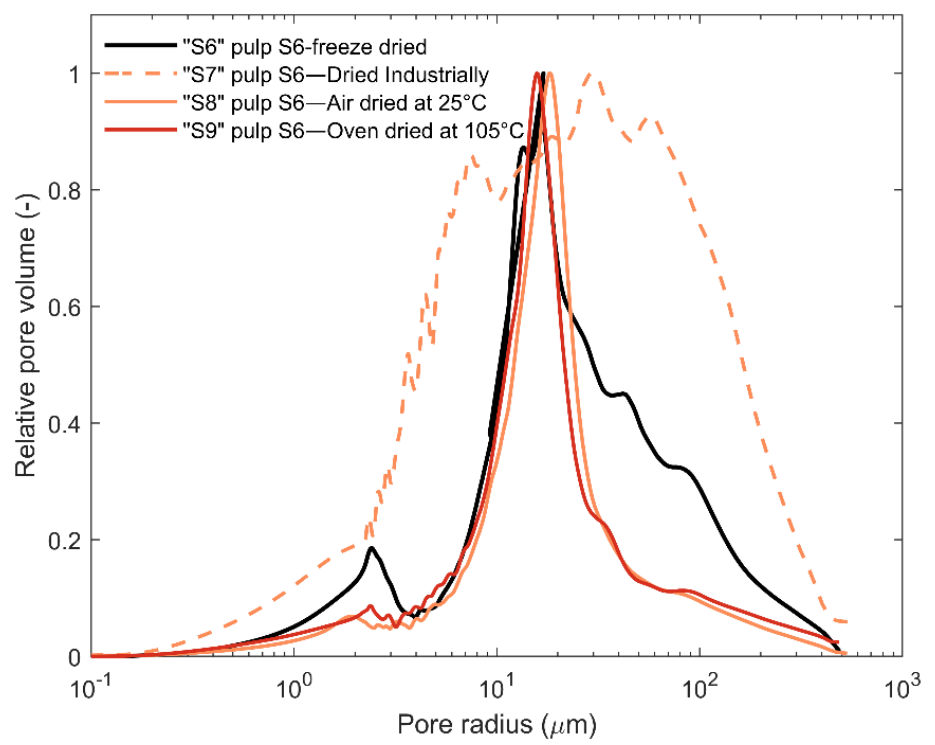

Fig. 5. Pore size distribution results for the dried final pulps derived from MIP: pulp S6- freeze dried, pulp S7- dried industrially, and pulps S8 and S9 were dried in the laboratory at two different temperatures $\left(25^{\circ} \mathrm{C}\right.$ for $\mathrm{S} 8$ and $105^{\circ} \mathrm{C}$ for S9). 
Figure 5 presents the changes in the pore size distribution of the pulp that was dried industrially (S7) and in the laboratory (S8 and S9). They are compared against pulp S6 which was processed in the same manner but freeze dried in the laboratory. The figure shows results for an identical pulp (S6) dried with four different techniques. What is most apparent is that the industrially-dried pulp had a much wider relative pore size distribution curve. While the other dried pulps exhibited two distinct peaks, only one was visible for the industrially dried pulp. Furthermore, of the drying methods examined, the freeze-dried pulp retains the highest amount of micron-sized pores. This difference in pore size distribution between laboratory and industrially dried pulps could be due to opening of macropores in the cell wall due to industrial drying. A similar behavior has been previously described by Joutsimo (2004) and Joutsimo and Asikainen (2013) as being the result of the mechanical treatment applied to pulps in laboratory, simulating pulp mill fiber line conditions.

\section{Pressure Plate}

The pore size distributions measured by the pressure plate technique are presented in Figs. 6 through 9.

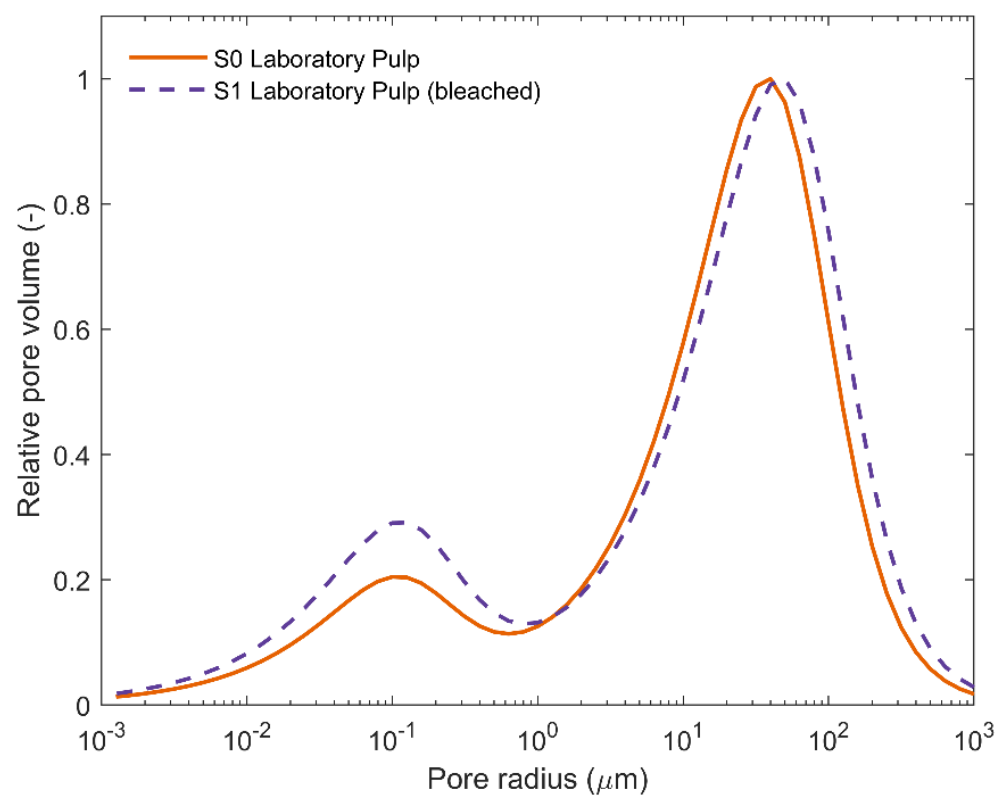

Fig. 6. Pore size distributions for the laboratory pulp from the cooking stage (SO) and after bleaching (S1) using pressure plate technique

Based on the results from the MIP and pressure plate technique, there appeared to be two dominant pore systems in the laboratory and industrial pulps. The largest pore size peak appeared at a pore radius of approximately $20 \mu \mathrm{m}$ to $40 \mu \mathrm{m}$. The smaller pore peak appeared at a smaller pore size (around $0.1 \mu \mathrm{m}$ ). The measurements of the laboratory pulp showed a slight difference between the bleached and unbleached conditions (Fig. 6). For the industrial pulp (Fig. 7), the peak of the pore distribution moved to a slightly larger pore size for S5 and S6, but it was virtually identical for S2, S3, and S4. 


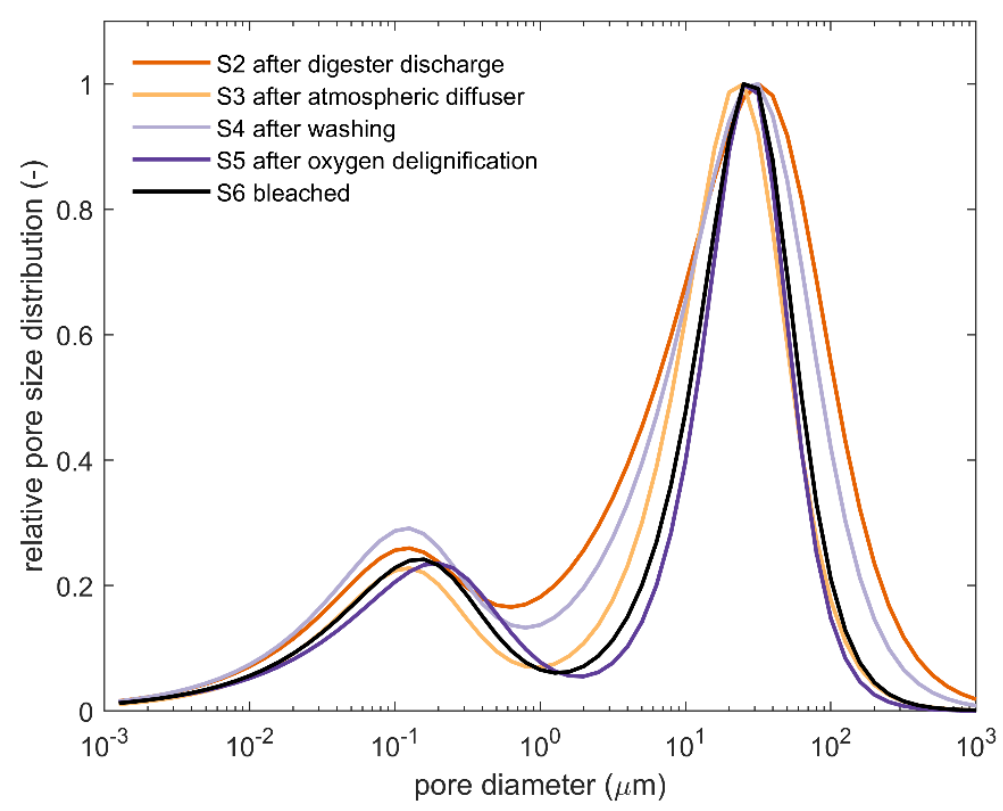

Fig. 7. Pore size distributions for the industrial pulp sampled during the process, from digester discharge to bleaching (S2 to S6) using pressure plate technique

The effect of the pulping process was most clearly apparent for the smaller of the two peaks. This peak occurred in the range of $10 \mathrm{~nm}$ to $1000 \mathrm{~nm}$ in the pressure plate data (Fig. 8) and $1 \mu \mathrm{m}$ to $3 \mu \mathrm{m}$ in the MIP data (Figs. 2 through 4). Likewise, the "valley" between the two peaks represents the absence of pores. For the dried pulps examined in MIP, these valleys occurred between 3 and $10 \mu \mathrm{m}$, whereas in the pressure plate measurements the valleys are wider, extending from less than $1 \mu \mathrm{m}$ to more than $10 \mu \mathrm{m}$.

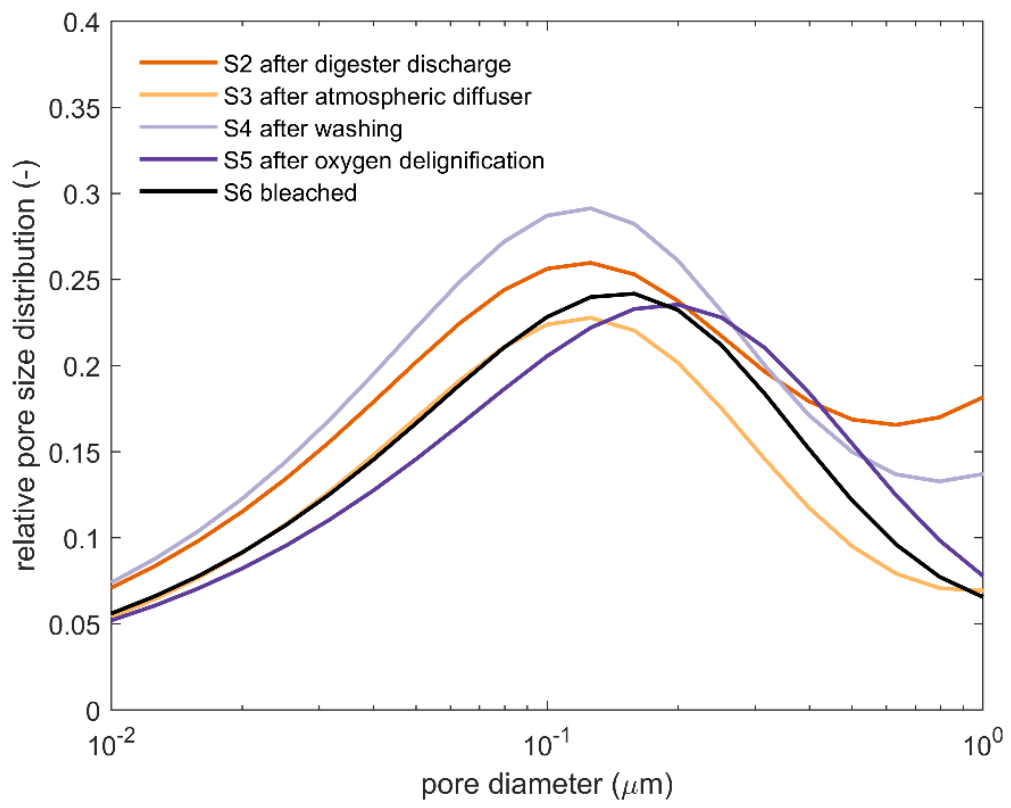

Fig. 8. Pore size distribution results over the range of $0.01 \mu \mathrm{m}$ to $1 \mu \mathrm{m}$ for the industrial pulp sampled during the process, from digester discharge to bleaching (S2 to S6) 
Figure 9 shows the relative pore size distribution of pulps that were dried and then rewetted in the range of $100 \mathrm{~nm}$ to $300 \mathrm{~nm}$ (smaller peaks) showed a reduction in the relative pore volume and shifted to a slightly higher pore radius for the industrially-dried pulp (S7) compared with the laboratory-dried pulp (S8 and S9).

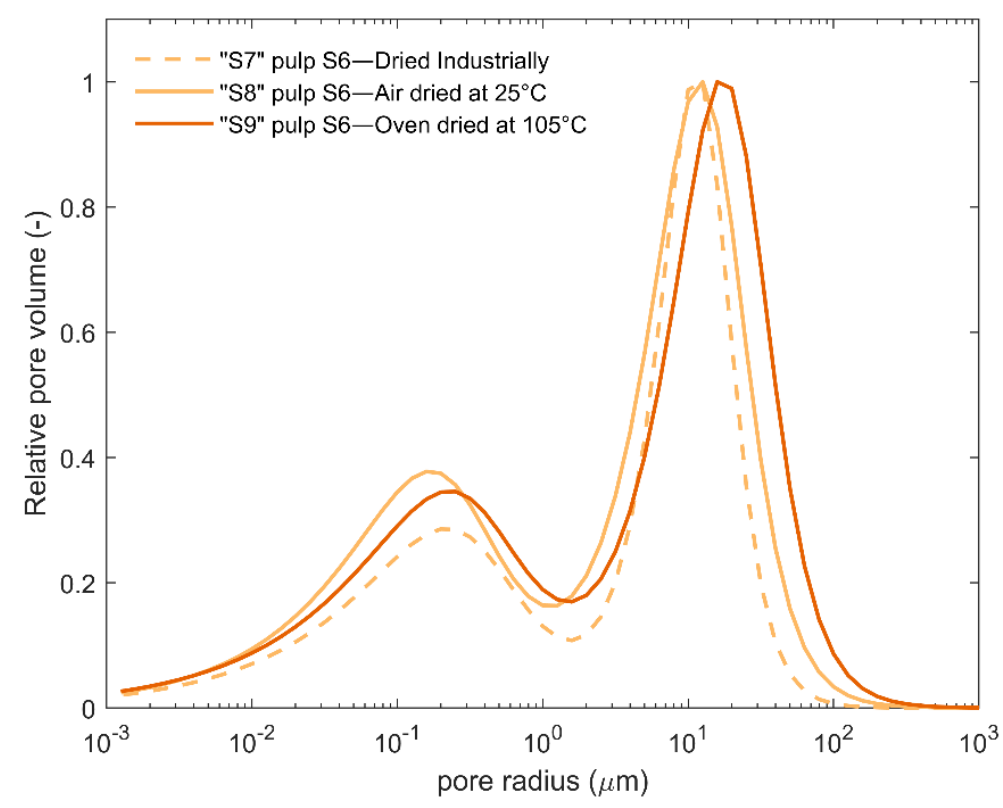

Fig. 9. Pore size distribution results for the dried final pulps derived from pressure plate: pulp S6freeze dried, pulp S7- dried industrially, and pulps S8 and S9 were dried in the laboratory at two different temperatures $\left(25^{\circ} \mathrm{C}\right.$ for $\mathrm{S} 8$ and $105^{\circ} \mathrm{C}$ for S9).

The pore size distribution results of the cell walls measured with the pressure plate technique and MIP showed an increase in the pore size distribution above $100 \mathrm{~nm}$ during processing and drying. According to Joutsimo (2004), the separation of structural elements occurred during processing increases irregularities in the surface of fibers and reduces bonding ability, which leads to changes in the strength, optical, and water holding properties. Along the same lines, Lovikka et al. (2016), using SEM analysis showed that large pores or cracks appeared on the surface of dried fibers, and that these pores were outside of the range of the traditional BET method.

Previous studies by Giacomozzi and Joutsimo (2015) and Giacomozzi and Joutsimo (2017) using NMR technique showed decreases in the pore volume and average pore sizes for dried pulp (pores under $220 \mathrm{~nm}$ in size), and increase in the inner crystallinity of the cellulose upon drying, which was also previously reported by other authors (Stone and Scallan 1965; Minor 1994; Duchesne 2001; Fernandes Diniz et al. 2004; Newman 2004; Brancato 2008).

Based on the above, it is hypothesized that, besides the changes in pore size distribution in the micropore ( $<2 \mathrm{~nm}$ ) and mesopore range ( 2 to $50 \mathrm{~nm}$ ), also the macropore range is affected by processing and drying, and further research is required on this field. In future studies in the macropore region, it is recommended to also include SEM as a complementary technique to MIP and pressure plate technique. 


\section{CONCLUSIONS}

1. Pore size distribution results for the radiata pine pulp measured by MIP showed that processing and drying induced changes in the cell wall structure.

2. The industrial pulp showed an increase in the relative pore volume in the range of 100 $\mathrm{nm}$ to $2000 \mathrm{~nm}$ (digester to bleaching) and a shift of the maximum pore size to lower values for pores in the range of $2000 \mathrm{~nm}$ to $10000 \mathrm{~nm}$ when the pulp was processed.

3. For measurements on dried pulps, the relative pore size distribution appeared quite different for the industrially-dried pulp when compared against the laboratory dried pulps.

\section{ACKNOWLEDGEMENTS}

The authors wish to express their gratitude to Celulosa Arauco y Constitución S.A. and Bioforest S.A. for the financial support of this study.

\section{REFERENCES CITED}

Allan, G. G., Ko, Y., and Ritzenthaler, P. (1991). "The microporosity of pulp: The nature of the pore size distribution," TAPPI J. 74(3), 205-212.

Andreasson, B., Forsström, J., and Wågberg, L. (2003). "The porous structure of pulp fibres with different yields and its influence on paper strength," Cellulose 10(2), 111123. DOI: $10.1023 / \mathrm{A}: 1024055406619$

Andreasson, B., Forsström, J., and Wågberg, L. (2005). "Determination of fibre pore structure: Influence of salt, $\mathrm{pH}$ and conventional wet strength resins," Cellulose 12(3), 253-265. DOI: 10.1007/s10570-004-5837-6

Anovitz, L. M., and Cole, D. R. (2015). "Characterization and analysis of porosity and pore structures," Reviews in Mineralogy \& Geochemistry 80(1), 61-164. DOI: 10.2138/rmg.2015.80.04

ASTM C1699-09 (2009). "Moisture retention curves of porous building materials using pressure plates,” ASTM International, 100 Barr Harbor Drive, PO Box C700, West Conshohocken, PA 19428-2959. United States

Berthold, J., and Salmén, L. (1997). "Inverse size exclusion chromatography (ISEC) for determining the relative pore size distribution of wood pulps," Holzforschung 51(4), 361-368. DOI: 10.1515/hfsg.1997.51.4.361

Brancato, A. (2008). Effect of Progressive Recycling on Cellulose Fiber Surface Properties, Ph.D. Dissertation, School of Chemical and Biomolecular Engineering, Georgia Institute of Technology, Atlanta, GA. DOI: 10.1.1.562.8354.

Carmeliet, J., and Roels, S. (2002) "Determination of the moisture capacity of porous building materials," Journal of Building Physics 25(3), 209-237. $10.1106 / 109719602022835$

Chinga, G. (2002). Structural Studies of LWC Paper Coating Layers Using SEM and Image Analysis Techniques, Thesis submitted in partial fulfilment of the Doktor 
Ingeniør degree, Norwegian University of Science and Technology, Department of Chemical Engineering.

de Ruvo, A., and Htun, M. (1983). "Fundamental and practical aspects of papermaking with recycled fibers," in: The Role of Fundamental Research in Papermaking, Vol. 1, J. Brander (ed.), Mechanical Engineering Pub. Ltd., London, UK, pp.195-225.

Duchesne, I., Hult, E-L., Molin, U., Daniel, G., Iversen, T., and Lennholm, H. (2001) "The influence of hemicellulose on fibril aggregation of kraft pulp fibres as revealed by FE-SEM and CP/MAS 13C-NMR," Cellulose 8(2), 103-111.

DOI: $10.1023 / \mathrm{A}: 1016645809958$

Fahlén, J., and Salmén, L. (2005). "Pore and matrix distribution in the fiber wall revealed by atomic force microscopy and image analysis," Biomacromolecules 6(1), 433-438. DOI: $10.1021 / \mathrm{bm} 040068 x$.

Fernandes Diniz, J., Gil, M., and Castro, J. (2004). "Hornification-its origin and interpretation in wood pulps," Wood Sci. Technol. 37(6), 489-494.

DOI 10.1007/s00226-003-0216-2.

Giacomozzi, D., and Joutsimo, O. (2015). "Drying temperature and hornification of industrial never-dried Pinus radiata pulps. 1. Strength, optical, and water holding properties," BioResources 10(3), 5791-5808. DOI: 10.15376/biores.10.3.5791-5808.

Giacomozzi, D., and Joutsimo, O. (2017). "Drying temperature and hornification of industrial never-dried Pinus radiata pulps. 2. Voith Sulzer refining," BioResources 12(1), 1532-1547. DOI: 10.15376/biores.12.1.1532-1547.

Giesche, H. (2006). "Mercury porosimetry: A general (practical) overview," Part. Part. Syst. Char. 23(1), 9-19. DOI: 10.1002/ppsc.200601009.

Hill, C., and Papadopoulos, A. (2001). "A review of methods used to determine the size of the cell wall microvoids of wood," Journal of the Institute of Wood Science 15(6), 337-345. ISSN 0200-3203.

ISO 534:2005 (2005). "Determination of thickness, density and specific volume," International Organization for Standardization (ISO), Geneva, Switzerland.

ISO 5264-2:2003 (2003). "Laboratory beating - Part 2: PFI mill method," International Organization for Standardization (ISO), Geneva, Switzerland.

ISO 23714:2007 (2007). "Determination of water retention value (WRV)," International Organization for Standardization (ISO), Geneva, Switzerland.

Jin, H., Nishiyama, Y., Wada, M., Kuga, S. (2004). "Nanofibrillar cellulose aerogels," Colloids and Surfaces A: Physicochem. Eng. Aspects 240(1-3), 63-67. DOI: 10.1016./j.colsurfa.2004.03.007.

Joutsimo, O. (2004). Effect of Mechanical Treatment on Softwood Kraft Fiber Properties, Ph.D. Dissertation, Helsinki University of Technology, Helsinki, Finland.

Joutsimo, O., and Asikainen, S. (2013). "Effect of fiber wall pore structure on pulp sheet density of softwood kraft pulp fibers," BioResources 8(2), 2719-2737. DOI: 10.15376/biores.8.2.2719-2737.

Kimura, M., Qi, Z-D., Fukuzumi, H., Kuga, S., and Isogai, A. (2014). "Mesoporous structures in never-dried softwood cellulose fibers investigated by nitrogen adsorption," Cellulose 21(5), 3193-3201. DOI: 10.1007/s10570-014-0342-z.

Kimura, M., Qi, Z-D, and Isogai, A. (2016). "Analysis of mesopore structures in wood cell walls and pulp fibers by nitrogen adsorption method," Nordic Pulp \& Paper Research Journal 31(2), 198-204. DOI: 10.3183/npprj-2016-31-02-p198-204. 
Li, T.-Q., and Henriksson, U. (1993). "Determination of pore sizes in wood cellulose fibers by ${ }^{2} \mathrm{H}$ and ${ }^{1} \mathrm{H}$ NMR," Nord. Pulp Pap. Res. J. 8(3), 326-330.

DOI: 10.3183/NPPRJ-1993-08-03-p326-330.

Lin, J. K., Ladisch, M., Patterson, J. A., and Noller, C. (1987). "Determining pore size distribution in wet cellulose by measuring solute exclusion using a differential refractometer," Biotechnol. Bioeng. 29(8), 976-981.

Lovikka, V. A., Khanjani, P., Väisänen, S., Vuorinen, T., and Maloney, T. (2016). "Porosity of wood pulp fibers in the wet and highly open dry state," Micropor. Mesopor. Mat. 234, 326-335. DOI: 10.1016/j.micromeso.2016.07.032.

Maloney, T. C., and Paulapuro, H. (1998) "Hydration and swelling of pulp fibres measured with differential scanning calorimetry," Nordic Pulp and Paper Res. J. 13(1), 31-36.

Minor, J. L. (1994). "Hornification-its origin and meaning," Prog. Pap. Recycl. 3(2), 9395.

Moura, M. J., Ferreira, P. J., and Figueiredo, M. M. (2005). "Mercury intrusion porosimetry in pulp and paper technology," Powder Technol. 160(2), 61-66. DOI: 10.1016/j.powtec.2005.08.033.

Newman, R. H. (2004) "Carbon-13 NMR evidence for cocrystallization of cellulose as a mechanism for hornification of bleached kraft pulp," Cellulose 11(1), 45-52. DOI: 10.1023/B:CELL.0000014768.28924.0c.

Park, S., Venditti, R., Jameel, H., and Pawlak, J. (2006). "Changes in pore size distribution during the drying of cellulose fibers as measured by differential scanning calorimetry," Carbohyd. Polym. 66(1), 97-103. DOI: 10.1016/j.carbpol.2006.02.026.

Roels, S., Elsen, J., Carmeliet, J., Hens, H. (2001). "Characterisation of pore structure by combining mercury porosimetry and micrography," Materials and Structures 34(2), 76-82.

Savitzky, A., and Golay, M. J. E. (1964). "Smoothing and differentiation of data by simplified least squares procedures," Analytical Chemistry 36(8), 1627-1639. DOI: $10.1021 / \mathrm{ac} 60214 \mathrm{a} 047$.

SCAN-CM 39:94 (1994). "Dry matter content," Scandinavian Pulp, Paper and Board Testing Committee (SCAN), Stockholm, Sweden.

SCAN-CM 40:01 (2001). "Size distribution," Scandinavian Pulp, Paper and Board Testing Committee (SCAN), Stockholm, Sweden.

SCAN-N 30:85 (1985). "Total, active and effective alkali," Scandinavian Pulp, Paper and Board Testing Committee (SCAN), Stockholm, Sweden.

SCAN-N 33:94 (1994). "Residual alkali (Hydroxide ion content)," Scandinavian Pulp, Paper and Board Testing Committee (SCAN), Stockholm, Sweden.

Stone, J. E., and Scallan, A. M. (1965). "Influence of drying on the pore structures of the cell wall. Consolidation of the paper web," in: Transactions of the $3^{\text {rd }}$ Fundamental Research Symposium, Cambridge, UK, pp. 145-167.

Stone, J. E., and Scallan, A. M. (1967). "The effect of component removal upon the porous structure of the cell wall of wood. Part II. Swelling in water and the fiber saturation point," TAPPI J. 50(10), 496-501.

Stone, J. E., and Scallan, A. M. (1968). "The effect of component removal upon the porous structure of the cell wall of wood. Part III. A comparison of the sulphite and kraft process," Pulp Paper Mag. Can. 69(12), 69-74. 
TAPPI 205 sp-06 (2006). "Forming handsheets for physical tests of pulp," Technical Association of the Pulp and Paper Industry (TAPPI), Atlanta, Georgia, USA.

TAPPI 220 sp-01 (2001). "Physical testing of pulp handsheets," Technical Association of the Pulp and Paper Industry (TAPPI), Atlanta, Georgia, USA.

TAPPI 257 cm-02 (2002). "Sampling and preparing wood for analysis," Technical Association of the Pulp and Paper Industry (TAPPI), Atlanta, Georgia, USA.

TAPPI 275 sp-12 (2012). "Screening of pulp (Somerville type equipment," Technical Association of the Pulp and Paper Industry (TAPPI), Atlanta, Georgia, USA.

Westermarck, S. (2000). Use of Mercury Porosimetry and Nitrogen Adsorption in Characterization of the Pore Structure of Mannitol and Microcrystalline Cellulose Powders, Granules and Tablets, Ph.D. Dissertation, Faculty of Science of the University of Helsinki, Finland.

Yamauchi, T. (2007). "A method to determine lumen volume and collapse degree of pulp fibers by using bottleneck effect of mercury porosimetry," J. Wood Sci. 53(6), 516519. DOI: 10.1007/s10086-007-0895-7.

Zelinka, S. L., Glass, S. V., Boardman, C. R., and Derome, D. (2016). "Moisture storage and transport properties of preservative treated and untreated southern pine wood," Wood Material Science \& Engineering 11(4), 228-238. DOI: 10.1080/17480272.2014.973443

Zillig, W., Janssen, H., Carmeliet, J., and Derome, D. (2006). "Liquid water transport in wood: Towards a mesoscopic approach," in: P. Fazio, H. Ge, J. Rao, and G.

Desmarais (eds.), Research in Building Physics and Building Engineering, Taylor and Francis Group, London, pp. 107-114.

Zillig, W. (2009). Moisture Transport in Wood using a Multiscale Approach, Ph.D. Dissertation, Katholieke Universiteit Leuven, Leuven, Belgium.

Article submitted: December 8, 2017; Peer review completed: June 5, 2018; Revised version received and accepted: January 28, 2019; Published: February 19, 2019.

DOI: $10.15376 /$ biores.14.2.2827-2841 